\title{
ERBB2 Gene Amplification Negative
}

National Cancer Institute

\section{Source}

National Cancer Institute. ERBB2 Gene Amplification Negative. NCI Thesaurus. Code C159897.

An indication that amplification of the ERBB2 gene was not detected in a sample. 